\title{
MINISTRY FOR THE UNIFICATION OF LAWS AND THE ORGANISATION OF ADMINISTRATION AND ITS ROLE IN THE PROCESS OF UNIFICATION OF CRIMINAL LAW IN THE INTERWAR CZECHOSLOVAK REPUBLIC ${ }^{1}$
}

\section{MINISTERSTVO PRE ZJEDNOTENIE ZÁKONODARSTVA A ORGANIZÁCIE SPRÁVY A JEHO ÚLOHA V PROCESE UNIFIKÁCIE TRESTNÉHO PRÁVA MEDZIVOJNOVEJ ČESKOSLOVENSKEJ REPUBLIKY}

\author{
Miroslav Fico \\ University of Pavol Jozef Šafárik in Košice, Faculty of Law \\ https://doi.org/10.33542/SIC2020-1-01
}

\begin{abstract}
After the formation of the Czechoslovak Republic, legal dualism in criminal law existed in our territory. It was based on the provisions of the so-called Reception Act, and therefore Austrian laws applied in the Czech part of the republic and Hungarian laws applied in Slovakia and Subcarpathian Russia. The dualism of criminal law was unsustainable in the long run. The main aim of the then ongoing processes was to unify criminal law, which was to reflect the unitary nature of the Czechoslovak Republic. The unification was to be implemented by passing criminal laws applicable in the entire territory of the newly formed republic. In the Czechoslovak Republic, the Ministry for the Unification of Laws and the Organisation of Administration was established, whose main role was to unify the laws and administration in the entire territory of the republic. In this paper, the author seeks to point out efforts to unify criminal law, with an emphasis on the activities of the Unification Ministry.
\end{abstract}

\begin{abstract}
ABSTRAKT
Po vzniku Československej republiky platil na našom území v oblasti trestného práva právny dualizmus. Vychádzal z ustanovení tzv. recepčnej normy, a teda v českej časti republiky platili rakúske právne predpisy a na území Slovenska a Podkarpatskej Rusi predpisy uhorské. Dualizmus trestného práva bol z dlhodobého hl'adiska neudržatelný. Hlavným cielom prebiehajúcich procesov bolo zjednotenie trestného práva, ktoré malo reflektovat' unitárny charakter Československej republiky. Unifikácia mala byt' realizovaná prijatím trestných zákonov, ktoré budú platné pre celé územie novovzniknutej republiky. VČeskoslovenskej republike došlo k zriadeniu Ministerstva pre zjednotenie zákonodarstva a organizácie správy, ktorého hlavnou úlohou malo byt'zjednotenie zákonodarstva a správy pre celé územie republiky. Autor sa v predloženom článku snaži o poukázanie na snahy o unifikáciu odvetvia trestného práva, s dôrazom na činnost' unifikačného ministerstva.
\end{abstract}

\footnotetext{
The paper has been prepared within Research Project APVV-16-0362: Privatisation of criminal law - the substantive, procedural, criminological and organisational and technical aspects.
} 


\section{INTRODUCTION}

After the formation of the Czechoslovak Republic on 28 October 1918, A. Rašín prepared the Act on the establishment of an independent state of Czechoslovakia, which was published under No. 11/1918. Section 2 of that so-called Reception Act stipulated that "all existing regional and imperial laws and regulations shall continue to be in force temporarily". In order "to avoid any confusion and to regulate an unobstructed transition to a new life of the State", the National Committee maintained the state existing at that time in the field of criminal law, as well. The provisions of the Reception Act resulted in the state of legal dualism - and even trialism in the early days - in the newly formed republic. ${ }^{2}$

A relatively short period of legal trialism stemmed from the provisions of Act No. 76/1920 of 30 January 1920 on the incorporation of the Hulczyn region. Under the provisions of the Treaty of Peace between the Allied and Associated Powers and Germany of 28 June 1919, the Czechoslovak Republic extended its sovereignty to a part of Upper Silesia. According to the provisions of that Act, laws and regulations which then applied in the incorporated Hulczyn region continued to apply if they were compatible with the change of the state sovereignty and if they were not amended or repealed by the laws and regulations of the Czechoslovak Republic. Therefore, German law continued to apply here. However, the laws of the Czechoslovak Republic which were published in the Collection of Laws and Regulations from 1 May 1920 also applied in the incorporated territory, unless those laws and regulations expressly stated otherwise. Laws which applied in the republic before 1 May 1920 or which were published in the Collection of Laws and Regulations of the Czechoslovak State entered into force in the incorporated territory on the date stipulated in individual cases by the government of the Czechoslovak Republic by a regulation published in the Collection of Laws and Regulations. Individual government regulations gradually changed the scope of application of Czechoslovak laws in the Hulczyn region, too. ${ }^{3}$ For this reason, after a short period of legal trialism, there was a change and transition to legal dualism in the Czechoslovak Republic.

Thus, after the formation of the republic, Austrian laws applied in Czechia, Moravia and Silesia, in substantive criminal law especially Criminal Code No. 117/1852 on crimes, misdemeanours and delicts. In Slovakia and Subcarpathian Russia, Hungarian laws were adopted and applied, especially Act V/1878 - Criminal Act on crimes and misdemeanours and Act XL/1879 - Criminal Code on delicts. ${ }^{4}$

Experts criticized the state of legal dualism, in principle, immediately after the formation of the Czechoslovak Republic. The legal dualism of Czechoslovak law was unsatisfactory in the long run. After the formation of the republic and the adoption of applicable Austrian and Hungarian criminal law, it was difficult, and in many aspects almost impossible, to understand and apply particular legislation parts. This was true for the majority of the population of the republic, but also for professionals, who in most cases only focused on one of these two legislation parts. In general, it can be stated that, given the state-law development in both parts of the former monarchy, there were only few experts in the originally Hungarian criminal law in Slovakia. In one of his articles, prof. Hexner stated in this respect that "we need to keep in mind the state of our legal system as a whole in order to reach the conviction of the enormous damage our government and our economic life suffer because of the lack of clarity

2 For more detail see, e.g.: VOJÁČEK, L.: První československý zákon (Pokus o opožděný komentář), Wolters Kluwer, Praha, 2018.

3 For more detail see, e.g.: VOJÁČEK, L. - KOLÁRIK, J. - GÁBRIŠ, T.: Československé právne dejiny (2. prepracované vydanie), EUROKÓDEX, s. r. o., Bratislava, 2013, p. 31, or STARÝ, M.: Právní trializmus československé republiky: K otázce recepce německého práva, In: 100 rokov od vzniku ČSR (zborník príspevkov zo IV. Ročníka medzinárodnej vedeckej konferencie „Banskobystrická škola právnych dejín“), BELIANUM, Banská Bystrica, 2018.

4 The terminology used was replaced in the Czechoslovak Republic by Act No. 449/1919 on the legal protection of the Czechoslovak Republic of 23 July 1919. Under Section 1 of that Act, the terms "Austrian", "Hungarian" and "AustroHungarian" were replaced in all laws and regulations by the terms "Czechoslovak", and "Czechoslovak Republic". That provision applied accordingly to the terms "imperial", "royal", "imperial royal", and "imperial and royal". 
in the laws. Today, the lay public, and often even an experienced lawyer, not being a specialist in a particular field of law, cannot answer the question of what legal relations apply to everyday situations. Determining the applicable law in a puzzle of diverse laws requires complicated study, the result of which is often only subjective." In one of his papers, prof. Karvaš stated in this respect that "the fact that we have two large areas in our country that are divided by the inconsistency of law means that the idea of a united country not only cannot take root, but on the contrary, as a result of dual law it prevents the artificial structural merger of these areas. The awareness that it is not a single country is being maintained, and in frequent economic relations even built." 6

In practice, the ignorance of the two legislation parts affected, for example, the activities of judges from Czechia who came to Slovakia after the formation of the republic, not knowing in detail the principles on which the former Hungarian criminal law was based. The concerns of judges about the ignorance of Hungarian law, with an emphasis on the liberality of law, were reflected, for example, in an article stating that "(...) the reputation of cruelty was more likely to apply to the former interpreters and collaborators of law, but not to the law itself, which, especially as regards criminal law, surprised by its modernity and liberality. The basic principles of law and criminal proceedings are based on completely different principles than in our lands. "7 Another problem arising from the adoption of the former criminal laws was also the translation of the laws into the national language, since the authentic text of the laws was written in Hungarian or German. ${ }^{8}$ That situation put pressure on the (re)publishing of individual criminal laws in the national language.

An important factor affecting the complexity of the then existing situation was the fact that many amendments of the above-mentioned basic substantive criminal laws were published even before the formation of the republic. Further provisions relating to criminal law were contained in the so-called secondary criminal laws. ${ }^{9}$ Thus, the situation existing in substantive criminal law created confusion and atomisation of legislation.

Similar processes - in terms of amendments and secondary criminal laws - extended/changed criminal law even after the formation of the Czechoslovak Republic. In the case of laws passed after the formation of the republic, it can be stated that they were already largely unifying in nature. However, even the unified laws that were passed after the formation of the Czechoslovak Republic often did not fully remove the chaotic nature of criminal law, since the former Austrian and Hungarian laws were based on different foundations in many aspects. In 1928, at the celebration of the $10^{\text {th }}$ anniversary of the republic, the journal PRÁVNÍK stated in connection with the unification of legislation that "if the entire fields of law have not been united, we cannot keep silent on the fact that partial unification has taken place in a lot of fields and issues. Depending on how strongly the adverse consequences of the existing legal dualism manifested themselves in life, a unifying act was made. Because this has been done in parts and in haste, this creates some difficulty for legal life, and we have several amendments not only for the same legal matter, for the same original law, but there

5 HEXNER, E.: Zriadenie legislatívneho archívu by bolo rentabilné, In: Hospodárstvo a právo, Volume II., No. 7, Bratislava, 1935, p. 2 (quoted from the description of the article filed in the archives of the Unification Ministry, NA Praha, Fond ministerstvo unifikačné, Box 12, p. 2.

6 The paper "Unifikácia práva a s ňou súvisiace problémy" was presented by prof. Karvaš at the inaugural meeting of the First Union Congress of Czechoslovak Lawyers on 26 September 1936, NA Praha, Fond ministerstvo unifikačné, Box 31, p. 1 .

7 SKÁLA, K.: Uhorské zákonodarstvo na Slovensku, In: PRÁVNÍK (Časopis venovaný vědě právní a státní), Právnická jednota v Praze (s podporou České akademie pro vědy, slovesnost a umění), Volume LVIII., Praha, 1919, p. 338.

8 For more detail see, e.g.: KALOUSEK, V.: O vyhlašovaní předpřevratových norem v jazyce státním, In: Právník, Právnická jednota v Praze, Volume LXXV., Praha, 1936, p. 297 et seq.

9 Secondary criminal laws were considered to be laws from other fields where certain wrongful acts constituted criminal offences falling within the jurisdiction of criminal courts (e.g., press, food, trademark, patent laws, etc.) - see, for example, MIŘIČKA, A.: Trestní právo hmotné (část obecná i zvláštní), Nákladem spolku československých právnikú „VŠEHRD“, Praha, 1934, p. 6. 
are also examples that a later amendment amends, repeals, or again amends the provisions set out in an earlier amendment. This creates confusion, which makes it difficult for a lawyer to understand and apply them and thus perform his profession."10 Similarly, the Supreme Court of the Czechoslovak Republic, in its opinion on the Outline of the Criminal Code in relation to the amendments and secondary criminal laws passed after the formation of the republic, stated that "the differences between the two criminal laws still in force in the Czechoslovak Republic are so profound that even the unification efforts that have been made since the coup to date under the pressure of necessity in the most urgent issues of substantive criminal law have only met with apparent success, since both general and special criminal law foundations under which the new common laws were to be applied have remained different." $" 11$

The main aim of the then ongoing processes was to unify criminal law, which was to reflect the unitary nature of the Czechoslovak Republic. The formation of the Czechoslovak Republic and its political unification were also to be accomplished through legal unification. ${ }^{12}$ The unification was to be accomplished by passing criminal laws applicable in the entire territory of the newly formed republic. The unification process was primarily to result in the passing of new criminal codes. This fundamental role in criminal law was also reflected as a priority in professional literature of that period. "Our task is to organise the legislative work of all the best heads of the Czechoslovak nation to create perfect, complete laws which will replace the Austrian and Hungarian laws and will form the basis of our republic's further development." $" 13$ The passing of new criminal codes - in the area of substantive criminal law the passing of the new Criminal Code, seemed to be accepted as a fundamental priority of the unification of criminal law. "Since these states (Czechoslovakia, Poland and Yugoslavia - the author's note) were formed from parts formerly belonging to different states with different legal systems, the first and most important task of the new states was to unite their populations as closely as possible, to raise their awareness of belonging to the new state and the awareness that now they can only achieve all their needs in their new state. An especially important means how to accomplish this is the unification of the legal systems in each state so that every citizen in his or her state can feel fully equal."14 The requirement of equality was also expressed in the Constitutional Charter of the Czechoslovak Republic and the unification of the legal system in the field of criminal law was to be its (natural) result. In view of the undesirable situation of legal dualism, the Ministry for the Unification of Laws and the Organisation of Administration was established in the Czechoslovak Republic, whose main role was to unify the legislation and the administration in the whole territory of the republic. One of the main sources of knowledge on the Ministry is the National Archives of Prague (hereinafter referred to as the "NA Praha"), with a special collection devoted to the Unification Ministry in 1919-1938. ${ }^{15}$ The aim of this paper is to analyse the activities of this Ministry - in the pro-

101918 - 1928, In: PRÁVNÍK (Časopis venovaný vědě právní a státní), Právnická jednota v Praze, Volume LXVII, Praha, 1928 , pp. 553, 554, (no author mentioned).

11 Opinion of the Supreme Court on the Outline of the Criminal Code (pres. 890/37), NA Praha, Fond ministerstvo spravodlivosti, Box 2070, p. 2.

12 For more detail see, e.g.: Deset let Československé republiky (svazek první), Vláda republiky Československé, Praha, 1928, (no author mentioned).

13 RÁTH, A.: Unifikácia, In: PRÁVNÍK (Časopis venovaný vědě právní a státní), Právnická jednota v Praze (s podporou České akademie pro vědy, slovesnost a umění), Volume LIX, Praha, 1920, p. 154.

14 LAŠTOVKA, K.: Po sjezdovém rokování, In: První sjezd právniků států slovanských v Bratislavě 1933, Nákladem generálního sekretariátu sjezdu, Bratislava, 1934, p. 168.

15 This collection was processed from 1962. The problem in relation to the preserved archival records of the collection was relatively extensive internal shredding. As a result of the shredding, the proposals of laws and regulations and other documents of the comment procedure, which were not commented, were discarded. Out of the original number of 1406 boxes, 246 have been preserved. They were divided into two collections (Unification Ministry 1919-1938 and Ministry for the Unification of Laws 1946-50). Currently, there are 179 boxes in the collection. The inventory of the collection was made by J. Krejč in 1963. Fond ministerstva unifikačného, inventár, pp. 9-10. 
cess of unification of substantive criminal law of the interwar Czechoslovak Republic in 1918-1938.

\section{ESTABLISHMENT OF THE UNIFICATION MINISTRY AND ITS ACTIVITY}

The Ministry for the Unification of Laws and the Organisation of Administration (hereinafter also referred to as the "Unification Ministry") was established by Act No. 431/1919 (of 22 July 1919) establishing the Ministry for the Unification of Laws and the Organisation of Administration in the Czechoslovak Republic. The government's proposal of the Act on the establishment of that Ministry was submitted to the National Assembly in July 1919 and was based on the above-mentioned need for the unification of the legal system. The establishment that Ministry was initiated by Slovakia. ${ }^{16}$ According to the report of the Constitutional Committee on the submitted proposal, "the task of the ministry in question will be to gradually bring about the unification of law and administration in the whole territory of our republic. To this end, it will be necessary not only to instate officials who are experts in both Austrian law and Hungarian law adopted by us, but also to establish an advisory council to work on drafting the unification laws. Naturally, the intention is not to implement the former Austrian law in Slovakia, but also to take from Hungarian law such aspects that seem to be better. In any case, there will be more opportunities for all legal matters to be reworked and codified according to the results of scientific research and the needs of our times. "17 The rapporteur of the submitted proposal was Dr. Bouček, who - after a brief presentation of the proposal and the opinion of the Constitutional Committee at the meeting held on 22 July 2019 - recommended that the National Assembly pass the proposal. ${ }^{18}$ The member of the National Assembly Dr. Stránský, the prime minister Mr. Tusar and Dr. Hodža spoke within the debate on the proposal. It was Milan Hodža (who later, in 1919-1920, held the position of the first minister of that Ministry) that pointed out the need for the establishment of that Ministry in the debate. In response to the consideration of dr. Stránský whether it would not be better to instate Slovak officials and experts to individual ministries than to establish a new ministry, Dr. Hodža pointed out an insufficient number of Slovak experts able to "penetrate the whole organism of central administration and all ministries. ",19

The purpose of the Ministry, defined in Section 1 of Act No. 431/1919 under which it was established, was to unify the laws and administration in the entire territory of the republic. The Ministry was established on a temporary basis and, according to the above-mentioned Act, its competence was to end when the stipulated objective was accomplished. Under Section 2, its competence and organisation were to be defined by the Ministerial Council. The implementation of that Act was imposed on the government.

On 29 December 1921, the Government of the Czechoslovak Republic passed Government Regulation No. 501/1921 implementing Act No. 431 of 22 July 1919, under which the Unification Ministry was competent to work and submit proposals for laws and regulations in order to unify laws which still applied pursuant to the Reception Act of October 1918 and were not unified (Section 1 of that Government Regulation laid down the basic competence of the Ministry). Section 2 of that Regulation identified areas not covered by the competence laid down in Section 1. Therefore, the Unification Ministry was not to deal with:

\footnotetext{
16 For more detail see, e.g.: Ministerstvo pro sjednocení zákonodarství a organisace správy, Nákladem ministerstva pro sjednocení zákonodarství a organisace správy, Tiskem státní tiskárny v Praze, Praha, 1921, p. 11 et seq., NA Praha, Fond ministerstvo unifikačné, Box 136.

17 Report of the Constitutional Committee on the Government Proposal of the Act on the Establishment of the Ministry for the Unification of Laws and the Organisation of Administration, available at https://www.psp.cz/eknih/1918ns/ps/tisky/t1364_00.htm.

18 Protocol of the $66^{\text {th }}$ Meeting of the National Assembly of 22 July 1919, available at https://www.psp.cz/eknih/1918ns/ps/stenprot/066schuz/s066001.htm.

$19 \mathrm{https} / / / \mathrm{www} . \mathrm{psp} . \mathrm{cz} / \mathrm{eknih} / 1918 \mathrm{~ns} / \mathrm{ps} /$ stenprot/066schuz/s066003.htm.
} 
(a) cases where certain legal relations were governed by laws of only one of the two legal systems adopted (Austrian or Hungarian);

(b) cases which involved not only a mere unification, but a reform of the existing laws;

(c) laws and regulations governing new legal relations which arose after 28 October 1918;

(d) regulations which were to be issued for the implementation of unified laws.

Under Section 3 of the Government Regulation, it was necessary to notify the Unification Ministry of the outlines of laws and regulations which also regulated the situation in Slovakia and Subcarpathian Russia, so that it could give its opinion on them. As needed, the Unification Ministry was also to be invited to cooperate in the preparatory work, given the importance of issues. Under Section 4 of the Government Regulation, the unification of laws was to be carried out in cooperation with other ministries, and possibly also in cooperation with other authorities and experts and, in case of accounting and audit regulations, in cooperation with the Supreme Audit Office, this everything according to an order to be drawn up by the Unification Ministry after agreement with the other ministries and after approval by the government of the republic. According to the Government Regulation, it was possible to deviate from such an approved order and also to leave the unification to a specialised ministry only in case of necessity. The first Work Regulations were approved by the government on 27 June 1924. If no agreement was reached between the ministries involved in disputed cases, the decision was made by the government. Under Section 5 of the Government Regulation, if a certain ministry had already begun work falling within the competence of the Unification Ministry, it was necessary to provide such a ministry with the widest possible support to complete it.

In connection with the establishment and activity of the Unification Ministry, it should be noted that it had "competency" disputes with other state administration authorities, ${ }^{20}$ during both its establishment and its further activities. As the Ministry itself emphasised in relation to the then ongoing process of unification of laws, the government did not fully transfer the unification role to the Ministry, but made the Unification Ministry a "supplementary element of a multi-member unification institution which had existed before the Unification Ministry was established, but had been unable to perform properly its own unification tasks because of a lack of knowledge of the Hungarian legal system " 21 Thus, the Unification Ministry did not primarily carry out its own unification activity by itself, but was, in the vast majority of its activities, placed in the position of some kind of cooperating body, mostly with the commenting competence. ${ }^{22}$ Efforts to reduce the number of ministries in the Czechoslovak Republic from 1922 also affected the Unification Ministry, which had to spend energy to fight for its preservation during its existence. ${ }^{23}$ At the same time, efforts were made to reorganise the Unification Ministry throughout the existence of the interwar republic ${ }^{24}$ and the Ministry had to continually struggle with a shortage of staff and funds. ${ }^{25}$

20 For more detail in this connection see, e.g., a comprehensive report by the Ministerial Counsellor and Head of the Administrative Department of the Ministry for the Unification of Laws and the Organisation of Administration: NERMUTH, A.: Působnost ministerstev, Praha, 1934, NA Praha, Fond ministerstvo unifikačné, Box 136.

21 Zprávy z oboru činností unifikačních (usporiadané odborovým radou J. Fritzom), NA Praha, Fond ministerstvo unifikačné, Box 10, p. 2.

22 NA Praha, Fond ministerstvo unifikačné, Box 10 contains several detailed reports on the activity of the Unification Ministry, prepared by its staff for individual calendar years.

23 For more detail see, e.g.: Resoluce, týkajíci se spojení agendy nekterých ministerstev a snížení celkového jich počtu /opis, No. 4634/, NA Praha, Fond ministerstvo unifikačné, Box 11.

24 Three alternative proposals of reorganisation of the Ministry, including the "remarks" of the Ministry on the proposals, have been preserved in the Ministry collection - for more detail see Reorganizace unifikace (No. 2046/26), NA Praha, Fond ministerstvo unifikačné, Box 11. The box also contains reports, meetings and other materials on the planned reorganisation of the Ministry.

25 For more detail see, e.g.: Výklad ministra pro sjednocení Msgra Dra Šrámka o čsl. právním sjednocení a o ministerstvu pro sjednocení zakonův a organisace správy, přednesený v ústavně-právních výborech obou sněmoven Národního shromáždení dne 20. a 21. listopadu 1935, p. 5 et seq., NA Praha, Fond ministerstvo unifikačné, Box 12. 
Another important problem arising from the adoption of former criminal laws was also the translation of the laws into the national language, since the authentic text of the laws was written in Hungarian or German. ${ }^{26}$ That situation thus put pressure on the (re)publishing of individual criminal laws in the national language. ${ }^{27}$ For this purpose, a translation department of the Unification Ministry was set up which was also to work on the definitive development of legal terminology. ${ }^{28}$ The above-mentioned area was one of the priorities of the activities of the Unification Ministry, which, however, was also limited by the amount of contributions from the state budget. During its existence, the Unification Ministry had to cope with limited budgetary resources - in all areas of its activities. This was also true in view of the fact that it was established as the last ministry at the time when other authorities were already at a much better level in terms of staff and material resources. ${ }^{29}$ The Unification Ministry received funds from the state budget to cover its printing expenses in an average annual amount of CZK $30,000^{30}$, which was not sufficient for the proper performance of the tasks required of it in this area. The translations of laws written in Hungarian, which were to be made primarily for the Ministry's own needs and for the needs of other authorities, were not provided by the Ministry in the required quantity and quality. ${ }^{31}$ This fact was repeatedly criticised by experts. The publishing activities of the Ministry were thus often entrusted to the private activities of various entities. However, despite the shortcomings and problems encountered by the Ministry, the Ministry's translation activity can also be assessed positively.

In relation to the unification of substantive criminal law in the Czechoslovak Republic - in the process of preparation of the general part of the Criminal Code the Unification Ministry sent its representative to the first consultations held in the summer months of 1920 aimed at the later publication of the Outline of the General Part of the Criminal Code in 1921. The preparation of the general part of the Criminal Code was entrusted to the so-called "select" committee for the reform of the Criminal Code. The chairman of the committee was prof. August Miřička and the Unification Ministry was represented Dr. August Ráth. Dr. Ráth only attended the first meetings as he later left for Comenius University in Bratislava. In preparing the proposals of criminal laws in the interwar republic (between 1918 and 1938, three codification proposals were prepared within the unification of criminal law, in addition to partial laws unifying criminal law: Proposal of the General Part of the Criminal Code of 1921, Preparatory Outline of the Criminal Act on Crimes and Misdemeanours and the Act on Delicts of 1926, and Outline of the Act issuing the Criminal Code of 1937), the advisory competence of the Unification Ministry was essential. The so-called "commenting" competence of the Unifica-

${ }^{26}$ For more detail see, e.g.: KALOUSEK, V.: O vyhlašovaní předpřevratových norem v jazyce státním, In: Právník, Právnická jednota v Praze, Volume LXXV, Praha, 1936, p. 297 et seq.

27 For more detail on the overcoming of the language problem and the language of the sources of laws adopted in Slovakia in the area of civil law in the interwar republic see: GÁBRIŠ, T. - ŠORL, T.: Občianske právo na Slovensku a unifikácia právneho poriadku v období prvej Československej republiky (1918-1938), In: Československé právo a právní věda v meziválečném období (1918-1938) a jejich místo ve střední Evropě (Volume 2), Univerzita Karlova v Praze, nakladatelství Karolinum, 2010, p. 646 et seq.

28 According to the general information of the Unification Ministry on the possibilities of the re-publishing of adopted laws, "the re-publishing of adopted laws can only fulfil its purpose in full if the existing German or Hungarian authentic texts of the adopted laws are replaced by the new authentic Czechoslovak text, if it adapts this new authentic text to later changes in the legal system while excluding the possibility for courts to review such a new decisive text in accordance with Article 102 of the Constitutional Charter, as regards both the correctness of the translation of the original authentic text and the admissibility of amendments or supplements which will be necessary because of subsequent - whether direct or indirect - changes in the legal system." - Republikace převzatých právních předpisů (No. 2550/1936), p. 2, NA Praha, Fond ministerstvo unifikačné, Box 128.

29 The Ministry was established in July 1919, the first minister Milan Hodža was appointed on 6 December 1919 and the first official was allocated to the Ministry on 29 December 1919. Even at the beginning of 1920 the Ministry had only four officials and struggled with a shortage of staff - Stručný prehled působnosti unifikačného ministerstva, NA Praha, Fond ministerstvo unifikačné, Box 10.

30 Deset let Československé republiky (svazek první), Vláda republiky Československé, Praha, 1928, p. 522.

31 The Unification Ministry issued, for example, Publications of the Ministry for the Unification of Laws and the Organisation of Administration, which were published as an annex to Právny obzor. 
tion Ministry meant that the proposals of all Czechoslovak laws and regulations were sent to the Ministry for consideration. ${ }^{32}$ In this context, the Unification Ministry was to ensure that the adopted Hungarian legal system, and in particular the economic, legal and political situation in Slovakia and Subcarpathian Russia, were taken into account. ${ }^{33}$ The Unification Ministry thus commented on almost all proposals of criminal laws of the period considered. By way of example, the comments/opinion of the Unification Ministry on that proposal (Titles I and II) were sent to the Ministry of Justice in the form of a note (No. 3635/1921/4) on 27 October $1922 .{ }^{34}$ Due to the relatively torsion-like archival material preserved in the collection of the Unification Ministry, it was naturally impossible to find all relevant archival records in the National Archives. The Unification Ministry also prepared comments on the proposal of the Act on Delicts. They were delivered to the Ministry of Justice on 12 January 1924 under No. $129 / 1924 .^{35}$ In relation to the above-mentioned proposals, the Ministry of Justice registers on its lists of received opinions and articles on the prepared proposals maintained by the Ministry of Justice - opinions of the Unification Ministry under No. 60791/22 (List No. 7) and No. 5894/24 (List No. 9). ${ }^{36}$ The Proposal of the General Part of the Criminal Code of 1921 was submitted, among others, to the committee of Slovak lawyers for criminal law in Bratislava through the Unification Ministry. The committee was established and held its meetings to analyse the submitted proposal and its comparison with Slovak law. The Unification Ministry later published the minutes of those meetings in a book form, as well. ${ }^{37}$ An extensive expert opinion on the Preparatory Outline of the Criminal Act on Crimes and Misdemeanours and the Act on Delicts of 1926 was prepared by the Unification Ministry on 27 July $1927 .^{38}$

In relation to the proposal of the Criminal Code of 1937, the Unification Ministry mainly acted in the comment procedure within the discussion of the Outline and the procedural steps of the authorities involved. In an effort to simplify and speed up the final work, on 9 April 1937 the Ministry of Justice sent proposals of directives under No. 20731-37 to the government under which the proposal was to be discussed at regular oral meetings of the representatives of ministries and criminal law experts. ${ }^{39}$ All ministries, irrespective of whether or not they attended the meetings, were to be subsequently informed of the outcomes in writing in the form of protocols sent to them. The protocols, together with their annexes, were also sent to the Supreme Court and the General Prosecutor's Office. Under point 5 of the directives, all ministries could send any further comments or objections within 14 days from the date of communication of the outcomes of the meetings. If they did not do so, they deemed to agree with the outcomes of the meetings. ${ }^{40}$ Those directives were approved in the form of the government resolution of 16 April 1937 and were binding on all the ministries. ${ }^{41}$ The directives were approved as proposed by the Ministry of Justice, with the sole exception regarding the

32 For more detail see, e.g.: Stručný přehled působnosti unifikačného ministerstva, NA Praha, Fond ministerstvo unifikačné, Box 10, str. 2.

33 For more detail see, e.g., the document "Ministerstvo pro sjednocení zakonův a organisace správy", NA Praha, Fond ministerstvo unifikačné, Box 11. Another "internal" document on the Unification Ministry was prepared by the staff of the Ministry in 1925 - O unifikačným ministerstvu, NA Praha, Fond ministerstvo unifikačné, Box 167.

34 NA Praha, Fond ministerstvo unifikačné, Box 120.

35 NA Praha, Fond ministerstvo unifikačné, Box 120.

36 NA Praha, Fond ministerstvo unifikačné, Box 120.

37 NOŽIČKA, J. (sp.): Zatímní návrh obecné části trestného zákona (záznamy z porad slovenské komise pro obor práva trestního v Bratislavě), Ministerstvo pro sjednocení zákonuv a organisace správy spolu s Právnickou jednotou na Slovensku v Bratislavě, Praha, 1924, (published by the Ministry for the Unification of Laws and the Organisation of Administration as "Príloha vestníka ministerstva pre zjednotenie zákonov a organizácie správy".

38 NA Praha, Fond Predsedníctvo ministerskej rady, Box 1772 (No. 1845/1927/5).

39 Such an intention was advised by the Ministry of Justice to the Ministerial Council Presidency on as early as 26 February 1937, in its letter Ref. 11470-37, stating that the Ministry of Justice intends to propose a similar procedure as applied by the government in speeding up the process of preparation of the Civil Code.

40 NA Praha, Fond Predsedníctvo ministerskej rady, Box 1772, No. 20731-37.

41 Extract from the Protocol on a meeting of the Ministerial Council, No. 9992-37, NA Praha, Fond Predsedníctvo ministerskej rady, Box 1772. 
date of beginning of an oral interministerial meeting (point 3 of the proposal). The Ministry of Justice proposed mid-September and by that date the individual ministries were to discuss the submitted Outline internally, as well as with individual interest and sectoral institutions, corporations and organisations belonging to their sphere of interest. The purpose of the proposal was that, at the beginning of the interministerial meeting, such a procedure was to eliminate "conflicting interests" within the individual ministries. The Unification Ministry disagreed with the proposed procedure, and it even disagreed with any fixed deadline. ${ }^{42}$ At the meeting of the Ministerial Council held on that issue, it was decided that the deadline proposed by the Ministry of Justice would be extended until 15 October 1937 and, at the same time, that its further extension necessary in case of particularly serious issues was to be agreed by those two ministries. ${ }^{43}$ At the same time, Dr. Nožička, as a representative of the Unification Ministry, worked in the expert committee under the patronage of the Ministry of Justice, which prepared the basic document/proposal.

\section{CONCLUSION}

Unification work in the Czechoslovak Republic in 1918-1938 was not only carried out (as it could appear from the very name of the established ministry) by the Unification Ministry, but by almost all the then existing ministries. The Unification Ministry was given an opportunity to adopt its opinion on the proposals of laws prepared by other ministries. As Dr. Šrámek, the then minister, stated in a report presented in the constitutional and legal affairs committees of both Houses of the National Assembly in 1935, "the Unification Ministry was not sufficiently equipped especially in terms of its competence, the unification agenda remained fragmented across all ministries, and this situation prevented the unification work from being based on an otherwise necessary, purposefully drafted and well thought out plan for the continuation of the unification of laws. " 44 During its existence in the interwar Czechoslovak Republic, the Unification Ministry actively participated in the unification work in the area of substantive criminal law - besides translation activities, mainly by actively commenting on the individual proposals of criminal laws.

The Ministry for the Unification of Laws and the Organisation of Administration was abolished by Government Regulation No. 269/1938 on the organisation of certain ministries of 4 November 1938. Under Section 3 of the Government Regulation, the competence of the Ministry ceased to exist. ${ }^{45}$ Its liquidation was entrusted to the Ministry of Interior.

\section{KEY WORDS}

Criminal Code, unification of criminal law, interwar Czechoslovakia, Unification Ministry

\section{KLUÚČOVÉ SLOVÁ}

trestný zákon, unifikácia trestného práva, medzivojnové Československo, unifikačné ministerstvo

42 NA Praha, Fond Predsedníctvo ministerskej rady, Box 1772, No. 1008/1937/D.

43 Extract from the Protocol on a meeting of the Ministerial Council, No. 9992-37, NA Praha, Fond Predsedníctvo ministerskej rady, Box 1772.

44 Výklad ministra pro sjednocení Msgra Dra Šrámka o čsl. právním sjednocení a o ministerstvu pro sjednocení zakonův a organisace správy, přednesený v ústavně-právních výborech obou sněmoven Národního shromáždení dne 20. a 21. listopadu 1935, p. 3, NA Praha, Fond ministerstvo unifikačné, Box 12.

45 For more detail see, e.g. document of the Unification Ministry "Likvidace ministerstva pro sjednocení zakonův a organisace správy" (No. 121 likv./1938), NA Praha, Fond ministerstvo unifikačné, Box 11. In relation to the liquidation, the box contains, for example, the liquidation plan prepared in November 1938 by Dr. Fritz. In 1938, Dr. Fritz drew up a relatively expensive expert opinion on the topic, including annexes, titled Reorganisace státní správy na podzim 1938 v oboru právního sjednocení, NA Praha, Fond ministerstvo unifikačné, Box 12. 


\section{BIBLIOGRAPHY}

1. Deset let Československé republiky (svazek první), Vláda republiky Československé, Praha, 1928, (no author mentioned).

2. GÁBRIŠ, T. - ŠORL, T.: Občianske právo na Slovensku a unifikácia právneho poriadku v období prvej Československej republiky (1918-1938), In: Československé právo a právní věda v meziválečném období (1918-1938) a jejich místo ve střední Evropě (svazek 2), Univerzita Karlova v Praze, nakladatelství Karolinum, 2010.

3. HEXNER, E.: Zriadenie legislatívneho archívu by bolo rentabilné, In: Hospodárstvo a právo, Volume II, No. 7, Bratislava, 1935 (quoted from the description of the article, NA Praha, Fond ministerstvo unifikačné, Box 12).

4. KALOUSEK, V.: O vyhlašovaní předpřevratových norem v jazyce státním, In: Právník, Právnická jednota v Praze, volume LXXV, Praha, 1936.

5. KARVAŠ, I.: „Unifikácia práva a s ňou súvisiace problémy“ (prednáška prednesená na slávnostnej zahajovacej schôdzi Prvého odborového zjazdu československých právnikov dňa 26. septembra 1936), NA Praha, Fond ministerstvo unifikačné, Box 31.

6. LAŠTOVKA, K.: Po sjezdovém rokování, In: První sjezd právniků států slovanských v Bratislavě 1933, Nákladem generálního sekretariátu sjezdu, Bratislava, 1934.

7. Likvidace ministerstva pro sjednocení zakonův a organisace správy“ ( $\mathrm{k}$ č. 121 likv./1938), NA Praha, Fond ministerstvo unifikačné, Box 11.

8. Ministerstvo pro sjednocení zákonodarství a organisace správy, Nákladem ministerstva pro sjednocení zákonodarství a organisace správy, Tiskem státní tiskárny v Praze, Praha, 1921.

9. MIŘIČKA, A.: Trestní právo hmotné (část obecná i zvláštní), Nákladem spolku československých právnikú „VŠEHRD“, Praha, 1934.

10. NERMUTH, A.: Působnost ministerstev, Praha, 1934, NA Praha (Fond ministerstvo unifikačné, Box 136).

11. NOŽIČKKA, J. (sp.): Zatímní návrh obecné části trestného zákona (záznamy z porad slovenské komise pro obor práva trestního v Bratislavě), Ministerstvo pro sjednocení zákonuv a organisace správy spolu s Právnickou jednotou na Slovensku v Bratislavě, Praha, 1924.

12. O unifikačným ministerstvu, Praha, 1925, NA Praha, Fond ministerstvo unifikačné, Box 167.

13. Posudok Najvyššieho súdu o osnove trestného zákona (pres. 890/37), NA Praha, Fond ministerstvo spravodlivosti, Box 2070.

14. RÁTH, A.: Unifikácia, In: PRÁVNÍK (Časopis venovaný vědě právní a státní), Právnická jednota v Praze (s podporou České akademie pro vědy, slovesnost a umění), Volume LIX, Praha, 1920.

15. Reorganisace státní správy na podzim 1938 v oboru právního sjednocení, NA Praha, Fond ministerstvo unifikačné, Box 12.

16. Reorganizace unifikace (č. 2046/26), NA Praha, Fond ministerstvo unifikačné, Box 11.

17. Republikace převzatých právních předpisů (č. 2550/1936), NA Praha, Fond ministerstvo unifikačné, Box 128.

18. Resoluce, týkajíci se spojení agendy nekterých ministerstev a snížení celkového jich počtu /opis, č. 4634/, NA Praha, Fond ministerstvo unifikačné, Box 11.

19. SKÁLA, K.: Uhorské zákonodarstvo na Slovensku, In: PRÁVNÍK (Časopis venovaný vědě právní a státní), Právnická jednota v Praze (s podporou České akademie pro vědy, slovesnost a umění), Volume LVIII, Praha, 1919.

20. STARÝ, M.: Právní trializmus československé republiky: K otázce recepce německého práva, In: 100 rokov od vzniku ČSR (zborník príspevkov zo IV. Ročníka medzinárodnej 
vedeckej konferencie „Banskobystrická škola právnych dejín“), BELIANUM, Banská Bystrica, 2018.

21. Stručný prehled působnosti unifikačného ministerstva, NA Praha, Fond ministerstvo unifikačné, Box 10.

22. VOJÁČEK, L.: První československý zákon (Pokus o opožděný komentář), Wolters Kluwer, Praha, 2018.

23. VOJÁC̆EK, L. - KOLÁRIK, J. - GÁBRIŠ, T.: Československé právne dejiny (2. prepracované vydanie), EUROKÓDEX, s. r. o., Bratislava, 2013.

24. Výklad ministra pro sjednocení Msgra Dra Šrámka o čsl. právním sjednocení a o ministerstvu pro sjednocení zakonův a organisace správy, přednesený v ústavněprávních výborech obou sněmoven Národního shromáždení dne 20. a 21. listopadu 1935, str. 5 a nasl., NA Praha, Fond ministerstvo unifikačné, Box 12.

25. Výt'ah z protokolu o schôdzi ministerskej rady, č. 9992-37, NA Praha, Fond Predsedníctvo ministerskej rady, Box 1772.

26. Zprávy z oboru činností unifikačních (usporiadané odborovým radou J. Fritzom), NA Praha, Fond ministerstvo unifikačné, Box 10. 1918 - 1928, In: PRÁVNÍK (Časopis venovaný vědě právní a státní), Právnická jednota v Praze, Volume LXVII, Praha, 1928, (no author mentioned).

27. https://www.psp.cz/eknih/1918ns/ps/tisky/t1364_00.htm

28. https://www.psp.cz/eknih/1918ns/ps/stenprot/066schuz/s066001.htm

29. https://www.psp.cz/eknih/1918ns/ps/stenprot/066schuz/s066003.htm

\section{CONTACT DETAILS OF THE AUTHOR}

JUDr. Miroslav Fico, PhD.

Assistant Professor

Pavol Jozef Šafárik University in Košice,

Faculty of Law, Department of History of the State and Law

Kováčska 26, 04001 Košice

Email: miroslav.fico@upjs.sk

Tel: +421552344131 